\title{
Piotr Michalowski
}

\section{Strategie skandalu i stereotypy odbioru*}

ABSTRACT. Michałowski Piotr, Strategie skandalu i stereotypy odbioru [The strategies of scandal and the stereotypes of reception]. "Przestrzenie Teorii" 2, Poznań 2003, Adam Mickiewicz University Press, pp. 73-88, ISBN 83-232-1333-X, ISSN 1644-6763.

The terms used in this title are connected - as two opposite kinds of reaction to the text and they exist outside: in conciousness of author and reader. Stereotype is necessary to hold intercourse; scandal is the effect of disturbance in communication but sometimes there is inversely: the communication bases on expectation of scandal - as particular convention. Scandal is a subjective phenomenon; it isn't an event, but it is a kind of response: protest or indignation. Most often it is created by media. This article is also the attempt formulate a small theory of scandal. It diferentiates accidental scandal from specially prepared one. Each of them is possible only it concerns the context of: person's life (1), point of view (2), custom (3) or artistic canon (4). In the first one scandal is connected with a message; in the rest - depends only on verbal act.

Stereotyp i skandal należą do tej samej grupy zjawisk społecznych. Obydwa rządzą mechanizmami komunikacji literackiej i są nieodłącznie związane $\mathrm{z}$ procesem recepcji. Pojęcia te, ze sobą nieoswojone i rzadko współwystępujące w jednym polu refleksji, z jednej strony ujawniają swą rozłączność i obcość, $z$ drugiej wykazują komplementarność, gdyż łączy je związek podwójny - podobny do oksymoronu: opozycyjność, ale zarazem cecha wspólna, jaką jest negatywność. Negatywnie nacechowany jest zarówno „stereotyp”, jak i „skandal”, choć drugi znacznie wyraźniej i częściej służy za określenie pejoratywne. Różnice waloryzacji obu pojęć dotyczą jednak nie tylko stopnia, ale i zakresu: mówiąc o „stereotypie” zbliżamy się bowiem do oceny estetycznej lub intelektualnej wypowiedzi, myśląc o jej wtórności i zbytnim uogólnieniu zawartego w niej sądu; natomiast miano „skandalu”, zarezerwowane dla sytuacji wyjątkowych, raczej dotyczy oceny etycznej.

To oczywiście wstępne rozpoznanie, narzucone przez praktykę języka potocznego, w którym obydwa hasła bywają ułatwiającym uproszczeniem opisu rzeczywistości, zazwyczaj służącym prędkiej dyskredytacji jakiegoś zdarzenia czy tekstu. Te konotacje negatywne trzeba jednak uchylić, aby dotrzeć do istoty mechanizmów rządzących nadaniem komunikatu i jego odbiorem. Okaże się wówczas, że posługujemy się bez-

* Tekst został wygłoszony na XXXI Konferencji Teoretycznoliterackiej (Uniejów, 1519 września 2002): „Stereotypy w literaturze (i tuż obok)”, zorganizowanej przez Katedrę Teorii Literatury Instytutu Teorii Literatury, Teatru i Sztuk Audiowizualnych Uniwersytetu Łódzkiego oraz Pracownię Poetyki Historycznej IBL PAN. 
krytycznie najbardziej rozpowszechnionym stereotypem „stereotypu” rozumiejąc go jako inwektywę i zarzut, a nie dopuszczając myśli o pozytywnych stronach zjawiska. Jeszcze trudniej za termin aksjologicznie neutralny uznać „skandal”. Jakakolwiek próba naukowego uściślania, a tym bardziej żonglowania tymi pojęciami, ujawnia już wyraźne napięcia semantyczne. Można pytać na przykład, czy stosowanie stereotypu jest skandalem? Albo na odwrót: czy doszukiwanie się skandalu w pewnej rzeczywistości nie jest zachowaniem stereotypowym. Konfrontacyjnie formułowane pytania wyznaczają dość rozległe pole możliwego dramatu rozgrywanego w "teatrze mowy”. Bo nie ma ani stereotypu, ani skandalu bez użycia języka.

Jak się wydaje, chodzi tu po prostu o dwie przeciwne reakcje odbiorcy na tekst. Takie wygodne założenie, które samo może być uznane za stereotyp, już domaga się rewizji, choć właśnie antynomia wydaje się najlepszym punktem wyjścia dla rozważań o relacji obu zjawisk. Najpierw trzeba jednak pozbawić "stereotyp" odium negatywności, w potocznym słowniku sytuującym to hasło w poblizu „banału”, "schematu”, „epigonizmu” czy „plagiatu”. Otóż nie o tak pojmowany „stereotyp” tu chodzi. Wprawdzie nie tylko w świadomości potocznej, ale i w naukach humanistycznych, a zwłaszcza na gruncie psychologii społecznej, dominują ujęcia akcentujące przede wszystkim ciemną stronę stereotypu, ale i tam zdarzają się podejścia neutralne, a tym samym holistyczne, w których negatywność cechuje tylko jeden jego rodzaj - „uprzedzenie”. Chodzi wówczas o zespól sądów opartych na uogólnieniach, wyprowadzonych $\mathrm{z}$ niekompletnych lub wręcz fałszywych przesłanek ${ }^{1}$. Natomiast $\mathrm{w}$ rozumieniu najszerszym stereotypem jest pewne wyobrażenie o charakterze upraszczającym, nadmiernie generalizujacym, sztywnym i odpornym na zmiany. W psychologii dotyczy najczęściej obrazu grup etnicznych, ale może być rozciągnięte jako reprezentacja umysłowa wszelkich kategorii społecznych ${ }^{2}$.

Propozycja ta nie zadowala jeszcze literaturoznawcy, który wolałby pojęcie odnieść wprost do tekstu, a najlepiej sklasyfikować jako kategorię poetyki - wszak mówi się zarówno o „schemacie”, jak i „stereotypie fabularnym". Lepiej pozostawić jednak tę kategorię na zewnątrz dzieła i wpisać w mechanizm komunikacji literackiej - po obu jej stronach, zakładając, że istnieje przed tekstem wyprodukowanym (w świadomości twórcy) i przed tekstem odebranym (w świadomości czytelnika). Zatem

1 Z. Chlewiński, Stereotypy: struktura, funkcje, geneza. Analiza interdyscyplinarna. w zbiorze: Stereotypy i uprzedzenia, red. Z. Chlewiński, I. Kurcz, Warszawa 1992, s. 13.

2 I. Kurcz, Stereotypy, prototypy i procesy kategoryzacji, w zbiorze: Stereotypy i uprzedzenia, op. cit., s. 33 . 
warto przyjąć, że chodzi o jakość wobec dzieła uprzednią (w podwójnym sensie), a utwór może jedynie w różny sposób do stereotypu się odnosić: odwoływać doń i go przekształcać, albo - biernie powtarzać i tym samym utrwalać.

Można uznać, że stereotyp wspomaga proces komunikacji, służąc w niej za pewien subkod, umacniający wspólnotę kontekstu nadawcy i odbiorcy3. Pogląd ten znajduje wsparcie $\mathrm{w}$ innym argumencie $\mathrm{z}$ obszaru psychologii społecznej i poznawczej: stereotyp umożliwia tak pożądaną redukcję nadmiaru informacji, choć $\mathrm{z}$ drugiej strony - utrudnia porozumienie z grupą posługującą się innym stereotypem. A więc już w takiej charakterystyce stereotyp okazuje się co najmniej ambiwalentny. Tym bardziej stanie się taki po dalszych ustaleniach: nie tylko bowiem chodzi o uproszczenie poprzez redukcję informacji, ale także o uzupełnienie pewnych elementów przy ich niedoborze ${ }^{5}$. Ta suplementująca wartość stercotypu odsyła z kolei do Ingardenowskich „miejsc niedookreślenia”, „wyglądów uschematyzowanych" i procesu konkretyzacji, a skojarzenie to umacnia tezę, że stereotyp nie tylko „sprzyja” przekazowi, ale stanowi jego warunek sine qua non. Stereotyp jest więc strukturą porozumienia, gwarantującą równowagę wyobrażeń u nadawcy i odbiorcy - podobną do tej, której na poziomie systemu języka odpowiadają uniwersalia. Bez niej byłoby niemożliwe jakiekolwiek poznanie nomotetyczne (a tym samym wszelka teoria) i pozostawałaby jedynie empiryczna idiografia.

Przy takich założeniach skandal może być uznany za odwrotność procesu porozumienia, albo - jego zakłócenie. Jeśli stereotyp odbioru, rozumiany jako pewne uniwersum możliwości informacji, stanowi zespół oczckiwań odbiorcy ${ }^{6}$, to skandal jako kategoria komplementarna mieściłby się $w$ polu nieoczekiwan. Stereotyp jednak zawiera informacje bliską zerowej (to znaczy nie zmieniającej wiedzy odbiorcy); skandal przeciwnie, dąży do maksymalnej zmiany stanu wiedzy. Niezależnie od wartościowania i ambiwalencji pojęć, antynomia jest wyrazista: innowacja przeciw redundancji, rewelacja przeciw repetycji. I zależność odwrotnie proporcjonalna: im więcej stereotypu, tym mniej miejsca pozostaje na skandal; im coś jest bardziej skandalizujące, tym mniej zawiera oczywistości.

Przeciwstawienie to zacznie się jednak zacierać wówczas, gdy uwzględnimy sytuacje zakłóceń komunikacyjnych, dokonywanych właśnie poprzez użycie stereotypu i - co tu zainteresuje bardziej - poprzez

${ }^{3} \mathrm{~K}$. Bartos zyński, Zagadnienie komunikacji literackiej $w$ utworach narracyjnych, w: tegoż, Teoria i interpretacja, Warszawa 1985, s. 116.

4 Z. Chlewiński, op. cit., s. 18.

5 I. Kurcz, op. cit., s. 39.

${ }^{6} \mathrm{~K}$. Bartoszyński, op. cit., s. 114-115. 
zastosowanie skandalu jako pewnej konwencji komunikacyjnej, zbliżającej horyzont oczekiwań odbiorcy do intencji nadawcy. Tymczasem jednak takie awansowanie pojęcia „skandal”, tradycyjnie zarezerwowanego dla zjawisk skrajnie negatywnych, do rangi równoprawnego czynnika komunikacji może budzić opór - jako samo w sobie „skandaliczne”. Wszak nie wszystko, co narusza przyzwyczajenia i jest wykroczeniem przeciwko oczekiwaniom odbiorcy, bywa od razu skandalem. Oczywiście, ale właśnie w tym polu skandal się mieści i tylko na nim on może „wybuchnąc” - bo właśnie „wybuch” jest jedyną formą jego efemerycznego istnienia. Skandal powstaje więc jako efekt zaskoczenia, na polu nieoczekiwań. Nie jest nim rewolucja (także artystyczna), gdyż ta dąży do ustanowienia nowego ładu aksjologicznego - jak twierdzi jeden ze "skandalologów”, Henryk Szabała ${ }^{7}$. Ale ta dystynkcja wydaje się wątpliwa wobec subiektywnej perspektywy oceny zjawiska: coś, co jedni zowią początkiem „rewolucji”, drudzy (ich przeciwnicy) nazwać mogą - waloryzując ujemnie i zarazem bagatelizując incydent, którego następstwa są jeszcze nieznane - właśnie „skandalem”; to, co najpierw jawi się tylko jednostkowym wybrykiem, przerodzić się może w proces dziejowy.

Jakkolwiek skandal wybucha jedynie wtedy, gdy naruszenie przewidywań czytelnika jest szczególnie dotkliwe i dotyczy wartości znacznie istotniejszych, zwłaszcza imponderabiliów, a nie jakiegokolwiek stereotypu w ogóle, to jednak jakością $\mathrm{w}$ tym procesie pośredniczącą musi być zawsze stereotyp.

O ile stereotyp wydaje się kategorią znacznie lepiej zadomowioną w humanistyce, znajdując wszechstronne oświetlenie: w filozofii, różnych kierunkach psychologii, estetyce i literaturoznawstwie, to o skandalu mówi się raczej okazjonalnie i co najwyżej na marginesie refleksji naukowej. Dlatego pouczający może być przegląd bieżących sytuacji użycia tego pojęcia. W internetowej Bazie Biblioteki Narodowej, odnotowującej polskie zasoby czasopiśmiennicze od $1996 \mathrm{r} .{ }^{8}$, słowo to pojawiło się w 37 tytułach. Większość z nich dotyczy zresztą gospodarki (o dziwo, wcale nie polskiej) albo polityki - $\mathrm{z}$ aferą Clintona na czele. Parokrotnie także innych zjawisk cywilizacyjnych, społecznych, a tylko raz - literackich, ale nawet i w tym wypadku chodzi raczej o przyległości literatury, o edytorstwo: jubileuszową edycję dzieł Mickiewicza9. Interesująco natomiast przedstawia się frazeologia nagłówków, gdyż słowo „skandal” wchodzi także w związki nieoczekiwane, w tym oksymoroniczne: Koniecznie soczysty skandal, Czarny skandal (choć mowa tu o spółkach węglowych),

7 H. Szabala, Skandal $w$ kulturze, w zbiorze: Wobec kryzysu kultury. Z filozoficznych rozważań nad kulturq wspólczesnq, red. L. Grudziński, Gdańsk 1993, s. 107.

8 http://mak.bn.org.pl/wykaz.htm (kwiecień 2002 r.)

9 J. Topolew ski, Skandal na rynku, „Kresy” 1998, nr 2, s. 116-128. 
Czeski skandal (jednak nie chodzi o odpowiednik „czeskiego błędu”, ale o dymisję Vaclava Klausa), Skandal na miare końca wieku (o funduszach emerytalnych w Wielkiej Brytanii), Cichy skandal (sic!), Skandal z klauzula poufne, Skandal mimo wszystko optymistyczny, Emerytalny sukces $i$ skandal, Skandal ubóstwa, Cialo to skandal...

Wyliczenie nagłówków publikacji prasowych z różnych dziedzin wykazuje duży rozrzut tematyczny. Zastanawia jednak przy tym oczywistość podejmowanej tu procedury wykrywania skandali: okazuje się bowiem, że ich poszukiwanie można prowadzić w świecie słów, a nie rzeczy. Ontologia zjawiska nie jest jednak tak oczywista. Wprawdzie skandal ma swą referencję poza tekstem, ale jego "wybuch" następuje dopiero w momencie „zdemaskowania”, a może nawet w samym akcie nominacji. Nie ma skandalu w rzeczywistości innej niż okrzyk wskazujący na pewne zdarzenie: „to skandal!”. I nie ma go tak długo, dopóki owa werbalna identyfikacja nie nastąpi. Oczywiście, są zdarzenia, wobec których to wskazanie pozostaje bardziej prawdopodobne, ale przecież nie ma faktów „skandalicznych" samych w sobie, lecz są skandaliczne zawsze „dla kogoś". Nie ma skandalu w sposób „obiektywny”. Chodzi zatem nie o fakt, ale o zakwalifikowanie zdarzenia, o jego subiektywną ocenę i rodzaj reakcji - silnie nacechowanej emocjonalnie. Nie ma skandalu dopóty, dopóki nikt jakiegoś faktu właśnie w ten sposób nie określi. Kwalifikacja zależy jednak od poczucia normy, a więc to, co dla jednego świadka choćby reprezentanta większości - jest skandalem, dla innego być nim nie musi. Co więcej: kontrowersja w ocenie jest warunkiem koniecznym skandalu. Ten relatywizm staje się tym wyraźniejszy, im bardziej rozchwiana jest norma (konwencja prawna, obyczajowa, towarzyska) lub gdy jej zastosowanie w konkretnej sytuacji pozostawia pewien margines nieoczywistości.

Tak liberalne postawienie sprawy może wzbudzić opór, choć zapewne nie będzie zarzewiem żadnego skandalu. Za ilustrację niech posłuży sytuacja wyjątkowo zagmatwana. Maciej Tramer szczegółowo analizuje jeden $\mathrm{z}$ międzywojennych skandali, jaki wybuchł podczas (a może tylko: wokół?) spektaklu nowej lichej komedii Krzywoszewskiego Pani Chorq$\dot{z} y n a$. Obecni na nim pikadorczycy, protestując przeciw zaniżaniu poziomu repertuarowego Teatru Polskiego, zakłócili przedstawienie, ale na temat tego, kto kogo hałaśliwie uciszał, są już w relacjach rozbieżności. Zatem to, co było demonstracją przeciw skandalowi (repertuaru scenicznego), samo stało się w opinii niektórych świadków skandalem. Czyli skandal przeciwko skandalowi? Może: „antyskandal"? W sprzecznych interpretacjach ocena incydentu, jak i ważne szczegóły faktograficzne, pozwalają mówić nie tylko o ambiwalencji skandalu i jego "przechodnim” charakterze, ale wręcz o odmiennej „treści” - wynikającej z przynależno-

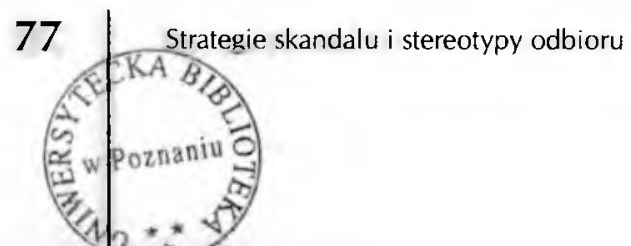


ści komentatora do określonego stronnictwa ${ }^{10}$. To dowód (choć zapewne nieco przewrotny), że skandal mieści się poza rzeczywistością przedmiotową (choć ta bywa w różnym stopniu skandalogenna) i oznacza pewien rodzaj reakcji świadka-odbiorcy: nieakceptacji, oburzenia, ostrego sprzeciwu. Wiadomo, że wybuch wyznacza uczestnikom pozycje „oburzonych” albo „oburzających”, ale trudno określić, którym z nich przyznać rolę podmiotu skandalu. Jest zatem domeną nie tekstu czy zdarzenia, ale sprawozdania. Mieści się więc w tym samym porządku co stereotyp.

Do równoprawnego potraktowania obydwu kategorii potrzebna jest jednak symetryczna wobec teorii stereotypu, przynajmniej mała teoria skandalu. Próby jej stworzenia na gruncie literaturoznawstwa podjęły już m.in. prace Edwarda Balcerzana $z$ dziedziny poetyki odbioru oraz dziejów futuryzmu ${ }^{11}$. Ponadto spośród opracowań nowszych, szczególnie przydatnych dla poruszanych tu zagadnień, na czoło wysuwa się monografia Macieja Tramera, w całości zjawisku skandalu poświęcona ${ }^{12}$.

Już wstępne rozpoznanie wykazało paradoksalność zjawiska a Tramer, jeden $\mathrm{z}$ czołowych teoretyków i zarazem historyków skandalu, $\mathrm{z}$ upodobaniem i w różnych wariantach powtarza taką oto aforystyczną definicję: "skandal jest tym, co istnieje tylko o tyle i tylko dlatego, że istnieć nie powinno"13. Nie cała to prawda, ale jej rozwinięcie obejmuje też inne cechy - jak wspomniana już subiektywność oceny i niesubstancjalność: „to nie przedmiot ale przymiot zdarzenia" 14 .

Mechanizm skandalu wydaje się bliski takim sytuacjom komunikacyjnym jak: dowcip, absurd, wreszcie metafora. Zbudowany na zasadzie podwójności i dysonansu, czy też niespójności między intencją a rezultatem, skandal powstaje wskutek awarii komunikacyjnej, pomyłki - rzeczywistej lub pozorowanej - jako efekt niefortunności zastosowanego aktu illokucyjnego. Jego pierwotna „niewinność” może być zastosowana w inscenizacji, w świadomie rozgrywanym „teatrze mowy” - choć niekoniecznie tak szlachetnym i bezinteresownym jak liryka. Skandal zaprogramowany (czyli sprowokowany) mieści się bowiem daleko od nieutylitarnej poezji, natomiast gdzieś w pobliżu takich zjawisk społecznych,

${ }_{10}$ M. Tramer, Literatura $i$ shandal. Na przykladzie okresu międzywojennego, Katowice 2000 , s. 117-130.

11 E. Balcerzan, Styl i poetyka twórczości dwujęzycznej Brunona Jasieńskiego, Wrocław 1968; Wstęp do: B. Jasieński, Utwory poetyckie, manifesty, szkice, WrocławKraków 1972; Paradoks o czytelniku, w: tegoż, Kręgi wtajemniczenia. Czytelnik. Badacz. Tlumacz. Pisarz, Kraków 1982; Literatura okrzyczana-literatura zakrzyczana, w: tegoż, Śmiech pokoleń - placz pokoleń, Kraków 1997.

12 M. Tramer, op. cit.

13 Tamże, po raz pierwszy na s. 12.

14 Tamże, s. 8. 
jak: intryga, podstęp, manipulacja, perswazja i można go uznać za odmianę wypowiedzi performatywnej.

Oprócz definicji warto się skupić na typologizacji, która wprowadzi podstawowe rozróżnienie. Jak już wynika z wcześniejszej uwagi, na pewno obok skandalu $\mathbf{z}$ przypadku istnieje skandal wykreowany. Trzeba jeszcze zauważyć, iż niezależnie od tej różnicy każdy skandal polega na naruszeniu przynajmniej jednego z czterech kontekstów społecznych odbioru komunikatu:

1) faktograficzno-personalnego - gdy ujawniając pewne fakty narusza czyjeś dobro osobiste, tworząc wizerunek osoby (lub innego wycinka rzeczywistości) sprzeczny $\mathrm{z}$ dotąd funkcjonującym; chodzi wówczas o pamflet, paszkwil, czy donos; o zdemaskowanie przestępstwa, ale także obrazę czy naruszenie tajemnicy prywatnej, wreszcie o pomówienie jeśli fakt nie zostal odkryty, ale zmyślony;

2) światopoglądowo-aksjologicznego - jeśli komunikat prezentuje poglądy sprzeczne $\mathrm{z}$ ogólnie przyjętymi, gdy godzi w „świętości” i nie liczy się $z$ dominującymi w społeczeństwie nastrojami; tu awaria polega na kolizji nie w obrębie wiedzy o faktach (dysonans poznawczy), ale wyłącznie na konflikcie oceny;

3) obyczajowego - jeśli porusza tematy „zakazane”, nie przewidziane normą do publicznego ogłaszania w mowie, piśmie, druku; chodzi więc o największe pole działania cenzury;

4) artystyczno-stylistycznego - jeśli komunikat zostaje sformułowany z naruszeniem normy artystycznej i językowego obyczaju, przyjętego w wypowiedziach publicznych (chodzi zarówno o drastyczne sposoby przedstawień, jak i tzw. wulgaryzmy).

Typologia ta wymaga jeszcze nadrzędnego podziału: $w$ pierwszym wypadku bowiem sytuacja zdecydowanie różni się od trzech pozostałych, gdyż skandal ma charakter sensacyjno-kryminalny i wynika z postawy czysto rewelatorskiej; niczego nie kreuje (przy założeniu prawdomówności), ale jedynie odkrywa pewne niezrelacjonowane wcześniej obszary rzeczywistości; ujawnia pewien stan rzeczy uprzedni, istniejący poza wypowiedzią i od niej niezależny. Natomiast w pozostałych przypadkach skandal nie zmienia stanu wiedzy odbiorcy, nie pełni więc funkcji poznawczej, ale nastawiony jest w znacznym stopniu na samą wypowiedź jako manifestowany akt przełamania tabu. Ujawnia też swą moc illokucyjną, dokonując jakiegoś przewartościowania czy zmiany nastawień. Wtedy jest przedsięwzięciem innowacyjnym, którego zresztą skrycie odbiorca pożąda: przełamania konwencji, czy raczej niegroźnego $\mathrm{w}$ niej przemieszczenia, które nie zburzy całkowicie dotychczasowych przyzwyczajeń, a ostatecznie być może utoruje drogę innym podobnym wyłomom i zrewolucjonizuje lub przynajmniej demokratycznie rozszerzy zakres normy. Jest więc skandal informacji obok skandalu werbalizacji. 
Jeżeli ten ostatni rozgrywa się na piśmie, chodzi o grę zwaną szeroko „literaturą”, w której reguły od początku świata (czy może nawet Słowa) są płynne, a granice ruchome. Jeśli odbywa się poza tekstem sztuki - staje się „literaturą stosowaną" - pisaną przez życie. Tak dzieje się zwłaszcza ze skandalem, którego nie wystarczy tylko zrelacjonować i „nagłośnić”, ale trzeba dopiero skonstruować, a nierzadko wręcz wykreować z niczego.

W codziennym doświadczeniu przyzwyczailiśmy się, że niektóre rejony rzeczywistości tworzą samoistnie pasma skandali, niejako wynikające $\mathrm{z}$ natury materiału fabularnego: życie polityczne i wydarzenia kryminalne (zresztą nie są to dziedziny wobec siebie całkiem suwerenne). Natomiast znacznie trudniej stworzyć i rozgłosić, albo: stworzyć poprzez rozpowszechnienie skandal o statusie faktu życia literackiego. Tu większość granic do przekroczenia została już przekroczona i pozostaje nuda powtórek. Ale jeśli już ktoś decyduje się na to karkołomne przedsięwzięcie, jakim jest prowokacja samym słowem czy dziełem, powinien przy preparowaniu sytuacji skandalogennej najpierw bezbłędnie spełnić wszystkie warunki ogólnej strategii skandalu. A są to:

1) atrakcyjność (sensacyjność) prezentowanego materiału,

2) moment zaskoczenia,

3) skuteczne rozpowszechnienie,

4) przewidywalna nieakceptacja lub akceptacja przez szok.

Sensacyjność wynika z gry między wiedzą a niewiedzą odbiorcy. Zaskoczenie $-\mathrm{z}$ gry między oczekiwanym a nieoczekiwanym. To ma być nagły cios wymierzony precyzyjnie w taki stereotyp odbioru, bez którego byłby w ogóle niemożliwy. Rozpowszechnienie zależy od aktywności dystrybutora książki, artykułu prasowego, plakatu czy plotki. Natomiast jeśli chodzi o czynnik czwarty, przewidywalną nieakceptację społeczną, to $\mathrm{w}$ skandalu zaplanowanym nie wchodzi w rachubę odrzucenie całkowite; musi wystąpić jakiś potencjal sporu, a więc chodzi raczej o kontrowersję, niż o jednogłośny sprzeciw. Zdarzenie, które prowokuje właśnie taką reakcję, ma znacznie lepszą perspektywę niż opór jednoznaczny i solidarny, gdyż ten zapewnia zwykle rozgłos krótkotrwały. Zatem gra musi toczyć się między aprobatą a dezaprobatą, przy czym należy unikać działań perswazyjnych zmierzających do zwycięstwa po którejś ze stron wzniesionej barykady i dążyć do maksymalnego przedłużenia bitwy, czy choćby utrwalenia schizmy w odbiorze.

Spełnienie tych warunków bynajmniej nie wystarcza i nie gwarantuje sukcesu prowokacji. Możliwych jest bowiem aż pięć na nią „odpowiedzi" odbiorcy, z których tylko pierwsza oznacza powodzenie organizatora; reszta to efekty niefortunnego zastosowania owej celowej „niefortunności”- jeśli rzecz wyrazić za pomocą teorii aktów mowy. 
1) podjęcie wyzwania, czyli oburzenie - a zatem wpadnięcie w pułapkę, które oznacza rzeczywisty wybuch skandalu; musi to być ponadto reakcja nie pojedyncza, ale zbiorowa i publicznie wyraźna, łatwo zauważalna;

2) masowe (skandalicznie masowe!) poparcie zdarzenia czy wypowiedzi, które miało skandal wywołać - to największa omyłka i najbardziej niespodziewany cios dla prowokatora, to nóż w plecy;

3) celowe wyciszenie lub inne działanie prewencyjne (np. konfiskata przez cenzurę) doprowadzające do niewybuchu lub eksplozji stłumionej, mało efektownej;

4) świadome niepodjęcie gry, uniknięcie zdemaskowanej pułapki - to jawne popsucie skandalu;

5) niepodjęcie gry ze względu na niezrozumienie granic normy lub tematu skandalu, a więc także - istoty dokonanego wykroczenia.

Uwagi te mogą zabrzmieć nazbyt instruktażowo (jak erystyka Schopenhauera), jednak nie jest moim celem pisanie vademecum skandalisty, lecz jedynie uogólnienie pewnych mechanizmów, które w różny sposób funkcjonowały już w historii życia literackiego.

Najważniejsze prace na ten temat skupiają się nie przypadkiem na okresie polskiego międzywojnia. To okres wyjątkowo obfity w literackie skandale i znaleźć można w nim ilustracje dla wszystkich odmian i rozmaitych przebiegów ${ }^{15}$. Zdarzały się najczęściej w poezji, gdzie skandalistami niejako „dyżurnymi” byli futuryści; właściwie cały ich program miał być wielkim skandalem, rozpisanym na skandaliczne epizody: poszczególne wiersze i zbiory, manifesty, jednodniówki i akcje artystyczne. Jeden tylko Bruno Jasieński nosił prowokacyjnie But $w$ butonierce, eksponował Rzygajace posagi i Palit Paryż. Futurystyczny skandal był modelem postępowania polegającym na „radykalnym zburzeniu hierarchii wartości, utrwalonej w społecznym obyczaju. Skandalista obraża wszystkich "dostojnych" i "ważnych» akcentując przy tym «ważność», chciałoby się powiedzieć: "najważniejszość własnej osoby»" - pisze Edward Balcerzan ${ }^{16}$. Jednak mimo ogromnego wysiłku bohaterów tych akcji, nie do hałaśliwych futurystów należą najgłośniejsze skandale dwudziestolecia może poza okolicznościami prawnymi konfiskaty jednodniówki Nuz $w$ bżuhu. W szeregu tym wymienia się raczej nazwiska inne, przede wszystkim Zegadłowicza, a ponadto: Tuwima, Wittlina, Lieberta, Uniłowskiego i Kurka. Nie ma natomiast na tej liście postaci o najbogatszej

${ }^{15}$ Epoki starsze takich opracowań mają nieporównanie mniej, choć przecież skandal nie jest wynalazkiem XX wieku. Tu warto wymienić pracę Jana Dürr-Durskiego Skandal jako czynnik oddzialywania spolecznego, w: Wstęp do: J. A. Morsztyn, Wybór poezji, Warszawa 1949.

${ }_{16}$ E. Balcerzan, Wstęp do: B. Jasieński, Utwory poetyckie..., op. cit., s. XLV. 
legendzie: Witkacego czy Gałczyńskiego. To nie przypadek. Skandal bowiem tyleż legendzie sprzyja, co ją niweczy; a największe eksplozje okazują się raczej efektem ubocznym eksperymentu, wynikającym z zawodowego ryzyka artysty, niż stanowią część metody autokreacji, literackiego programu czy sposobu bycia.

Zegadłowiczowi przyznaje się czołowe miejsce pośród międzywojennych skandalistów - bynajmniej nie dlatego, że napisał rzecz w tym okresie „najmocniejszą", a tym bardziej nie ze względu na notoryczność skandalizowania. Przeciwnie: liczy się bowiem kontrast między dotychczasowym obrazem autora a nowym jego dziełem, a więc - siła zaskoczenia. Pisze Henryk Szabała: „Aura skandaliczności jest tutaj wprost proporcjonalna do stanu utożsamienia danej osoby $\mathrm{z}$ normą moralną, im bardziej dana osoba była nosicielem, gwarantem danego kanonu społecznego, któremu się sprzeniewierzyła, tym bardziej rozległy jest skandal"17. Najmniejszą szansę wywołania skandalu paradoksalnie mają więc osoby nisko cenione, nie cieszące się powszechnym uznaniem, bez autorytetu, a zwłaszcza zdyskwalifikowane jako odmieńcy, szaleńcy, oryginały czy nawet grafomani. Autorzy nie dopuszczani na Parnas nie mogą być zeń relegowani. Zegadłowicz natomiast, zanim wydał „skandaliczne" Zmory (1935), uznany był za pisarza katolickiego, cenionego zwłaszcza jako „beskidzki świątkarz”. Samemu autorowi nie zależało na nagłej utracie tej pozycji, a nawet przypuścić można, iż nie wiedział, że wydaje książkę odważną ${ }^{18}$. Tym bardziej nie sposób tu mówić o „strategii skandalu", ale raczej o „wypadku przy pracy”.

Podobnie przydarzyło się Tuwimowi - tyle, że aż czterokrotnie. Poeta ten stanowi fenomen omyłek, wynikłych z niezdolności trafnego przewidywania. Albo - jest to przykład osobliwie niebezpiecznej alienacji tekstu. Pierwszym skandalem, u progu międzywojnia, stał się dytyramb Wiosna, który wzbudził oburzenie językiem i tematyką, a został nazwany "grzechem śmiertelnym przeciw pięknu”"19. Protest dotyczył zatem „nieartystyczności" tekstu, a nie zawartych $\mathrm{w}$ nim rewelacji obyczajowych. Podjęty został w imię Sztuki i w obronie jej „czystości”, wobec której grzechem było „zniżenie się do prawdy” - prawdy zresztą przez nikogo nie kwestionowanej. Chodziło więc o atak artystycznego arystokratyzmu na próbę demokratyzacji języka poetyckiego. Ten skandal był raczej zamierzony jako programowy gest „wyjścia poezji na ulicę”, choć zapewne okazał się nazbyt zamaszysty, gdyż spowodował niezamierzony rozpad redakcji czasopisma, w którym wiersz opublikowano (odrodzonego potem jako „Pro Arte”).

${ }^{17}$ H. Szabała, Skandal w kulturze, op. cit., s. 104.

${ }^{18} \mathrm{M}$. Tramer, op. cit., s. 87.

19 List otwarty do Juliana Tuwima, „Pro Arte et Studio” 1918, nr 11. 
Dwa następne skandale wywołane przez utwory Tuwima miały już inny charakter - jednak nie chodzi tylko o ich aspekt polityczny. Autor został oskarżony o zamach na władzę i sfery wojskowe, a na ostrość ataku nałożyła się jeszcze antysemicka nagonka, w ramach której postulowano rozszerzenie anatemy na wszystkie utwory Tuwima, łącznie z usunięciem wierszy dla dzieci zamieszczonych w Elementarzu Falskiego. Istotna jest jednak nieintencjonalność tych zdarzeń, a co więcej: brak u „sprawcy" orientacji w nastrojach przyszłej publiczności. Jeśli chodzi o wiersz Do prostego człowieka, opublikowany 27 października 1929 r. w „Robotniku”, to jednak trudno nazwać „niefortunnością” datę i okoliczności prasowego pierwodruku: tuż przed rocznicą odzyskania niepodległości. W grę wchodzi nie tylko przypadek, ale i świadoma prowokacja ze strony autora albo manipulacja ze strony wydawcy, który zdecydował o takiej synchronizacji faktów; być może współkształtowały zdarzenie wszystkie te czynniki. Wiersz jest tak jednoznacznym apelem pacyfistycznym, że trudno posądzać Tuwima o całkowity brak rozeznania w polityce; pewne jest natomiast to, że skandalu się nie spodziewał i że się go wystraszyl. Natomiast w przypadku wiersza Do generałów reakcje były niejednoznaczne - nawet (a może: zwłaszcza) w najwyższych sferach sił zbrojnych, do których utwór zostal zaadresowany. Swiadek zbiorowej lektury w Ministerstwie Spraw Wojskowych, Mieczysław Lepecki, stwierdza wręcz, że głośne odczytanie utworu w końcu uspokoiło poruszonych dygnitarzy ${ }^{20}$. Mimo to gdzie indziej - w kampanii prasowej - utwór skandalem okrzyknięto, choć trudno ocenić proporcje czytelników oburzonych do tych, którzy wyrażone w nim poglądy podzielali. Przypadek ten uświadamia, że nie literacka publiczność kreuje skandal, ale ośrodki opiniotwórcze, a więc głównie media.

Ciekawe, że były to wybuchy niekontrolowane, co zresztą wydaje się charakterystyczne dla ich sprawcy - poety obdarzonego niezbyt dobrą samoświadomością twórczą, a więc i nie przewidującego skutków, jakie może wywołać jego alchemia słowa (zresztą podobna w efektach do pasji dzieciństwa: piromanii). Można uznać, że w jakiejś mierze były to skandale z przypadku - częściowo wynikające z prowokacyjnej szczerości tekstu, ale na skandal nie nastawione.

W 1936 r. powstal poemat Bal w operze, który jednak zyskał rozgłos znacznie później. Tu można mówić z jednej strony o świadomej prowokacji - bo nie sposób inaczej traktować dzieła, które w założeniu ma charakter satyry politycznej; $\mathrm{z}$ drugiej strony - o niewybuchu skandalu,

${ }^{20}$ M. Lepecki, Warszawa - Lizbona - Rio de Janeiro, w zbiorze: Wspomnienia o Julianie Tuwimie, red. W. Jedlicka i M. Toporowski, Warszawa 1963, s. 204-205. Relację tę ciekawie analizuje M. Tramer jako tendencyjną waloryzację postaw i osób oraz pośrednią apoteozę autora (op. cit., s. 150-152). 
gdyż konfiskata dokonana przez cenzurę skazała tekst na publikację we fragmentach i "drugobiegowych" odpisach, natomiast oficjalnie został opublikowany dopiero po wojnie. Można więc mówić raczej o „skandalu prawa", ale gdy chodzi o recepcję - jedynie o skandalu potencjalnym.

Niemniej wymienione utwory okazały się ważkimi głosami w życiu społecznym, artykułując poglądy wprawdzie skrajne, ale przecież nie odosobnione i nie oderwane od społecznej empirii, przeciwnie - trafnie demaskujące kulisy obyczajowości, polityki i ustroju. Niewiele natomiast pozostało po obrazoburczych gestach futurystów - demonstracyjnie zamaszystych, a więc i niewiarygodnych. Zaledwie legenda - niezdolna wpłynąć ani na losy świata, ani na bieg historii, ani nawet - historii literatury. Nie każda rewelacja artystyczna oznaczała od razu rewolucję i nie każda rewolucja była zamierzona jako akt prowokacji, który doprowadzi do wybuchu skandalu. Przeciwnie, prowokować miały przede wszystkim nurty postulujące zmiany powierzchowne, czy nawet pozorne, ale spektakularne. Skandal nie interesował natomiast poważnych eksperymentatorów, zamkniętych w swych laboratoriach słowa. Osamotniona Awangarda Krakowska nie szukała rekompensaty w tanich efektach mających przysporzyć jej popularności za wszelką cenę - a tym bardziej za cenę jeszcze większego niezrozumienia. Eksperymenty służyły misji odnowy poezji, a nie sezonowemu gwiazdorstwu i jeśli zdarzył się tu jakiś skandal, oznaczał porażkę nowatora.

Obliczona na skandal poetyka, drastycznie niezgodna $z$ kanonem przede wszystkim stylistycznym, w mniejszym stopniu np. formą otwartą lub „czystą" - należy jednak, jak się wydaje, do bezpowrotnej modernistycznej przeszłości. Pozostają zabawy albo nostalgiczne cierpienia z powodu uwiądu tej awangardowej strategii. Działalność krakowskiego „BruLionu”, śląskiej grupy Na Dziko czy działającego w Berlinie Związku Polskich Nieudaczników21 wydaje się tylko wyblakłą repliką pomysłów z lat dwudziestych. Fiasko w tych przypadkach upoważnia do sformułowania jeszcze jednej zasady: skandalu nie można powtarzać.

Maciej Tramer proponuje rozróżnienie: "skandalicznej literatury" (w której chodzi o naruszenie obyczajowości) od "skandalu literatury” (gdzie chodzi o naruszenie zasad artyzmu)22. Dystynkcję tę (w praktyce trudno uchwytną, bo wymagającą odcedzenia warstwy stylu od kompozycji) z uwagi na mylące podobieństwo nazw, można zastąpić zaproponowanym wcześniej czwórpodziałem dokonanym według kontekstów społecznych. Warto ponadto jeszcze wyraźniej oddzielić sferę tekstu lite-

21 Zob. P. Lekszycki, Grupa Na Dziko. Socjologia i poetyka zjawiska, Katowice 2001; prezentacja Związku Polskich Nieudaczników, obejmująca historię i manifesty; „Pogranicza” 2002, nr 2.

${ }^{22}$ M. Tramer, op. cit., s. 97. 
rackiego od okoliczności jego recepcji, wyróżniając: skandal literacki i skandal okołoliteracki - chociaż równie wiele przemawia za tym, by $\mathrm{z}$ tego podziału jako sztucznego zrezygnować.

Skandal „czysto” literacki, jakim było kiedyś naruszenie kanonu estetycznego (opisany casus Tuwimowej Wiosny), wydaje się dziś niemożliwy: od dawna nie istnieje żadne artystyczne tabu i hałaśliwe przekraczanie granic (rzeczywiste, a nie pozorowane) skończyło się razem z wyczerpaniem awangardy. Od dawna nośnikiem skandalu nie może się stać poezja - przynajmniej odkąd porzuciła skamandrycką utopię egalitaryzmu i przestała „wychodzić na ulicę". Laboratoryjne spory szkół poetyckich toczą się wokół detali, które nie są w stanie zaabsorbować szerszego odbiorcy: gry słowne, powtórkowe refleksy i smakowane przez koneserów półcienie zadomowionych poetyk, poniewieranie tej czy innej tradycji - to wszystko motywy nazbyt subtelne, by mogły stanowić materiał na skandal, nadający się do rozpowszechnienia masowego. W języku nie może nim być wulgaryzm, określany anachronicznie jako „niecenzuralny", choć od dawna przez cenzurę niezagrożony i używany powszechnie w prozie, poezji i dramacie. Nie może nim być nawet anakolut czy inny (za Białoszewskim) „wypadek z gramatyki”. Tym bardziej - błąd drukarski. Ani dewiacje znaczeń. Także nie język poetycki. Tym bardziej nie poezja w ogóle. I nie literatura. Wreszcie nawet nie historia literatury - jak sugerował Hans Robert Jauss ${ }^{23}$. Wszystko, co dziś w literaturze chce zaistnieć jako skandal, wykazuje niemoc emerytowanego prowokatora i nie może już liczyć na większy wydźwięk. Toteż ani stylistyczne wybryki, ani inne immanentne cechy tekstu nie są nośnikiem skandalu, ale dopiero okoliczności recepcji. Pośród stereotypów „otwartych na skandal" ważniejsze od konwencji literackich są dziś na pewno konteksty społeczne.

W gruncie rzeczy $\mathrm{w}$ strategii skandalu chodzi zawsze o jakiś obszar rzeczywistości pozaliterackiej. Także Jasieński walczył o „futuryzację życia, a sztuka była zaledwie drogą wiodącą do tego celu ${ }^{24}$. W sensie węższym chodzi o pewien styl czytania, nazwany przez Balcerzana „recepcjonizmem detektywistycznym", który może być źródłem intryg najwyżej „paraliterackich"25. Nie dziwi więc, że areną takich rozgrywek są przede wszystkim gatunki auto- i biograficzne. Najbardziej skandalizujące (a zarazem jeśli chodzi o ich ocenę etyczną: skandaliczne) dotyczą nie literatury, ale osoby autora: mieszczą się w tej grupie "rewelacje” Joanny

${ }^{23}$ H. R. Jauss, Historia literatury jako prowokacja, przeł. M. Lukasiewicz, Warszawa 1999.

${ }^{24}$ H. Zaworska, Polskie programy artystyczne lat 1917-1922, Warszawa 1963, s. 128.

${ }^{25}$ E. Balcerzan, Literatura zakrzyczana - literatura okrzyczana, op. cit., s. 160-161. 
Siedleckiej o Kosińskim, Witkacym i Gombrowiczu oraz paszkwil Krajskich Dwie twarze Wislawy Szymborskiej26. Ale i w tych przypadkach energia skandalu się wyczerpuje, bowiem niezależnie od dotkliwości skutków moralnych, każda następna książka wymienionych autorów będzie już skandalem znacznie mniejszym albo całkowicie utraci ten status, gdyż wpisze się $\mathrm{w}$ coraz rozleglejszy horyzont oczekiwań, a nazwisko autora na okładce posłuży za czytelny sygnał uprzedzający o zawartości. Skandal trudno poddaje się eskalacji, a wygnanie autora z Parnasu nie może być powtórzone, toteż trudno zostać skandalistą zawodowym. Bo skandal jest precedensem, a nie procederem.

Dzisiejsze skandale okołoliterackie mają przebieg raczej podskórny i krótkotrwały, a obieg - często zamknięty środowiskowo. Po latach pozostaje po nich $\mathrm{w}$ historii literatury jakiś niekonieczny plotkarski suplement: anegdota, legenda - z trudem dająca się obronić jako „ślad przełomu” czy choćby „wydarzenie”. Skandale rozgrywają się poza samą literaturą lub co najwyżej na jej styku z życiem, i to przede wszystkim nieliterackim. W tych spektaklach literatura odgrywa rolę zaledwie halabardnika, a pierwszoplanowe stają się konteksty pozaliterackie. Do wyjątków należą: zdemaskowany plagiat, precedens zawłaszczenia autorstwa, czy przeciwnie - przypisania go komuś innemu, a więc różne formy mistyfikacji: od pseudonimu po allonim. Także - przyznanie lub nieprzyznanie nagrody literackiej, choć to już domena krytyki literackiej.

Skandal można waloryzować dodatnio, choć $\mathrm{z}$ reguły umożliwia to dopiero perspektywa historyczna lub zdystansowany ogląd badawczy filozoficzny, antropologiczny, teoretycznokulturowy. Może być interpretowany jako „bunt w świecie wartości”27. W strategii mieszczą się zatem także jaśniejsze punkty. Pośmiertna popularność autorów, czy też lepiej: ich „za grobem zwycięstwo", następuje po rozpętaniu skandalu niedocenienia i związanego $\mathrm{z}$ nim impetu rewindykacji; dochodzi bowiem do rewanżu, w którym wyrównane być mają „rachunki krzywd” doznanych za życia.

Wydaje się, że dyskusja (której szczyt przypada w Polsce na rok 2002) nad rozdzieleniem dwóch funkcji mediów między tzw. „programy misyjne" (sic!) i komercyjne, dotyczy właśnie odmiennej relacji do stereotypu. Pierwsze programy mają go przeksztalcać (a stereotyp negatywny zwalczać w ramach reedukacji), drugie - na nim żerować, troszcząc się

26 J. Siedlecka, Czarny ptasior, Gdańsk-Warszawa 1994; wyd. 2 rozszerz., Warszawa 1998; Mahatma Witkac, Warszawa 1998; Jaśnie panicz, Kraków 1987; wyd. 3 poszerz. i uzup., Warszawa 1997; E. i St. Krajscy, Dwie twarze Wislawy Szymborskiej, Warszawa 1996.

${ }^{27}$ H. Szabała, Skandal jako bunt w świecie wartości, „Folia Philosophica” 1999, nr 17, s.119-137. 
jedynie o „wysoką oglądalność”. Na pozór więc tylko te pierwsze są „otwarte na skandal”, który dla drugich byłby zabójczy. Otóź jest zupełnie inaczej. Niewątpliwie największe znaczenie zyskuje dziś skandal medialny. Formuła ta brzmi nieco tautologicznie, gdyż właśnie przekaz stanowi warunek sine qua non skandalu, który jest zjawiskiem z założenia medialnym - czy też, jak chce McLuhan, sam ,przekaz jest komunikatem"28.

Trzeba wrócić do wątpliwości zasygnalizowanej we wstępie: czy skandal ma spełniać oczekiwania odbiorcy (jak stereotyp), czy też przeciwnie: ma być policzkiem tym oczekiwaniom wymierzonym, a więc-dramatem niespełnienia, w którym konflikt wynika $\mathrm{z}$ rozdźwięku między czytelniczym popytem a podażą. Czy jest działaniem koniunkturalnym, czy té̇ antykoniunkturalnym? Doświadczenie uczy, że obydwa ujęcia dadzą się ze sobą nie tylko pogodzić, ale i ściśle powiązać - przykładem jest choćby zapotrzebowanie na horror, na szok nowości, ale także na każdą inną niespodziankę, bez której utwór literacki traci rację istnienia. Podobnie przecież może się dziać w przypadku kolizji zaplanowanej, w którą wkalkulowano negatywną reakcję odbiorcy, a więc - kiedy się zastosuje "podwójny nelson" jako chwyt bardziej wyrafinowany w manipulowaniu procesem recepcji. Różny może być „czytelniczy horyzont oczekiwania”, warunkujący określony styl odbioru ${ }^{29}$. Wtedy status skandalu określa tak zrekonstruowana intencja kreatora: „Otrzymasz to, co cię ma oburzyć, ale czego w gruncie rzeczy najbardziej pragniesz". Ten chwyt znajduje także zastosowanie w reklamie i promocji książki - co jednak jest już tematem na osobną opowieść.

Znowu metoda futurystów jest przykładem modelowym. Już oni zrozumieli bowiem, że burzenie systemów na dłuższą metę byłoby nudne. Dlatego odświeżali system działań: w ramach obowiązującej w strategii skandalu zasady niekonsekwencji i programowych samozaprzeczeń, uznali, że chwytem, który zagwarantuje efekt największego zaskoczenia, będzie demonstracyjne wycofanie się w tradycjonalizm - oczywiście jedynie na tle wcześniejszych wystąpien antytradycjonalistycznych, do których publiczność zdążyła przywyknąć. Rozumieli, że kontekst społeczny rządzi się pewnym mechanizmem przyzwyczajenia, za którym trzeba nadążać i które trzeba przekraczać - również wstecz, kiedy już się nie da inaczej. Była to zarówno apoteoza konia (zamiast kultu maszyny), jak i sylabotonik (na tle postulowanej nowoczesności wiersza) ${ }^{30}$.

${ }_{28}$ M. McLuhan, Przekaźniki, czyli przedlużenie czlowieka, w: tegoż, Wybór pism, przel. K. Jakubowicz, Warszawa 1975, s. 45.

${ }^{29} \mathrm{~K}$. Bartos zyński, Odbiór a konwencje literackie. (Kilka myśli schematyzujących), w zbiorze: Teoretyczne tematy $i$ konwencje, red. J. Sławińskiego, Wrocław 1986.

${ }^{30}$ E. Balcerzan, Wstęp do: B. Jasieński, Utwory poetyckie..., op. cit, s. XLVI. 
W takim ujęciu skandal jest po prostu jedynie pewną bardziej złożoną strategią retoryczną. Dochodzimy więc do sytuacji przewrotnej, która znosi wyjściową opozycję: skandal staje się stereotypem i zostaje wprzęgnięty w mechanizm komunikacji. Zostaje wchłonięty, zasymilowany, przeniesiony na pole oczekiwanych możliwości. Swiadomość odbiorcy zbliża się tym samym do postawy nil admirari. Napięcie, czyli różnica potencjałów między podażą a popytem, jest więc w dużym stopniu pozorowane.

Związki między rozpatrywanymi kategoriami są zatem wielorakie. Najpierw funkcjonalne, a pośród nich zachodzi przede wszystkim już wspomniana zależność podstawowa: naruszenie stereotypu może być źródłem skandalu, natomiast realizowanie stereotypu przed skandalem zabezpiecza. Jednak atak na stereotyp wcale nie gwarantuje wybuchu skandalu. Zachodzi jeszcze inny związek: warto się zastanowić, czy możliwe jest wywołanie skandalu poprzez użycie stereotypu? Albo prościej: czy stereotyp może być powodem skandalu? Raczej trudno to sobie wyobrazić - chyba tylko wtedy, gdy chodzi o jakiś krzyczący anachronizm, np. ogłoszenie na kongresie astrofizyków, że jednak Ziemia jest płaska. Ale taki wybryk byłby prawdopodobnie odczytany tylko jako niestosowny żart. Może natomiast się zdarzyć odwrotnie: można wpaść w zastawioną przez siebie pułapkę; organizując przemyślny skandal - popaść w stereotyp. To chyba największa klęska prowokatora - sklasyfikowana wcześniej jako typ reakcji 2). Przyzwyczajenie do skandalu wytworzyło (szczegółowo opisane $\mathrm{w}$ monografii Tramera) mechanizmy represji: prewencję cenzury, wykluczenie z literackiego salonu czy instrumentalną interpretację faktu jako spisku żydowsko-bolszewicko-masońskiego. Reakcje te (a więc właściwie: skandale) są równie stereotypowe (czy nawet: rytualne) jak hołdy składane pisarzom jako wyraz społecznej aprobaty dla ich dokonań. Skandal bywa więc jeszcze jednym stereotypem odbioru - skrajnym, ale nierzadko zapewniającym twórcy $\mathrm{w}$ historii literatury nieśmiertelność, nie zawsze zasłużoną. 